\title{
Anaesthetic Effect of Ocimum gratissimum Extract on Oreochromis niloticus Juveniles
}

\author{
Adewale $A Y^{1}$, Adeshina $I^{2}$ and $Y_{\text {usuf }} \mathrm{OY}^{2}$ \\ ${ }^{1}$ School of Environmental Life Sciences, Faculty of Science and Built Engineering, Deakin University, Australia \\ ${ }^{2}$ Department of Aquaculture and Fisheries, University of Ilorin, Nigeria
}

${ }^{*}$ Corresponding author: Adeshina I, Department of Aquaculture and Fisheries, University of Ilorin, Nigeria, Tel: +2347054994559; E-mail: padibra4all@yahoo.co.uk

Received Date: December 06, 2016; Accepted Date: February 22, 2017; Published Date: March 01, 2017

Copyright: @ 2017 Adeshina I, et al. This is an open-access article distributed under the terms of the Creative Commons Attribution License, which permits unrestricted use, distribution, and reproduction in any medium, provided the original author and source are credited.

Citation: Adewale AY, Adeshina I, Yusuf OY. Anaesthetic Effect of Ocimum gratissimum Extract on Oreochromis niloticus Juveniles. Eur Exp Biol. 2017, 7:7.

\section{Abstract}

This study examined the use of $O$. gratissimum oil as anesthetic in $O$. niloticus juveniles. Ten fish with average weight $(36.0 \pm 1.6 \mathrm{~g})$ were allocated to five rectangular tanks $(50 \times 34 \times 27 \mathrm{~cm})$ containing 35 litres using completely randomized design in triplicates and a control. The experimental treatment (dose) were prepared using 1:20 of extract oil and ethanol in five concentrations $(0,20,40,60$, 80 and $100 \mathrm{mg} / \mathrm{l}$ ) and exposed for twenty minutes before transferred in to recovery tanks. The data obtained were analyzed using descriptive statistics, ANOVA, Duncan multiple range test to separate the means and regression analysis. The results show that concentration of $100 \mathrm{mg} / \mathrm{l}$ anesthetized highest number of fish $(10.00 \pm 0.00)$ while the least was observed in $20 \mathrm{mg} / \mathrm{l}(1.67 \pm 1.53)$ within three minutes. Fastest recovery was observed in fish anesthetized with the $20 \mathrm{mg} / \mathrm{l}$ of oil while $100 \mathrm{mg} / \mathrm{l}$ had the least mean recovered fish $(1.00 \pm 1.00)$ within three minutes. There are relationships among induction time $\left(R^{2}=0.892\right)$, concentration of oil and recovery time $\left(R^{2}=0.905\right)$. However, $60 \mathrm{mg} / \mathrm{l}$ is considered adequate for the anesthetic of $O$. niloticus.

Keywords: Experimental treatment; Fish culture; Anesthetic; 0 . gratissimum

\section{Introduction}

The Oreochromis niloticus is an important fish culture by many fish farmers in Nigeria. It is also attracts high market value because of its widely acceptability in the country and therefore it has occupy a priority position in a delicacy list. However, today aquaculture practices require handling during measuring, weighing and some biological examinations, thereby subjecting the fish to unavoidable stress. To minimized the stress, chemicals such as tricaine methanesulphonate is been used but the uses of chemicals are been discourage because of its residual effects in the tissues of the fish, expensive nature of the drugs and increasing advocate for organic aquaculture. However, previous studies have reported the used of clove oil as anaesthetic material in fish [1-3]. Fish handlers usually sustain injuries during handling of $O$. niloticus because it has several fins making it difficult to handle. Activities such as blood taking and transportation are common practices in today aquaculture research therefore, expose fish to trauma, pester and anxiety leading to loss of mobility and loss of balancing among others [4]. O. gratissimum (Lamiaceae), commonly known as "alfavaca" also known as "Efinrin" in Yoruba language is a native to Africa [5]. In Nigeria, the plant grows virtually in all regions. It could be found in many farms, residential and industrial areas. It grows and survives well in south-west of Nigeria and could be found at backyard where it is not intentionally planted.

The plant has been use for many purposes ranging from human consumption to its application in traditional medicine in Nigeria. It has good aroma and it leaves has become delicacy and serves as spicy for fish and meat products such as Kilishi, Dembu, Yaji etc. Many authors reported that the plant has some chemical compounds with antimicrobial properties such as eugenol, linaol, methyl cinnamate, camphor and thymol $[6,7]$. It has been demonstrated in the previous studies that eugenol (75-98\%) isolated from 0 . gratissimum is the major antimicrobial component which inhibit and kill gram-positive bacteria and fungi $[8,9]$.

In spite the enormous activities on $O$. niloticus, there is paucity of information on the use of naturally derived anesthetics to manage both intentional and unintentional stress hence the need for this study. In adequate application of anesthetics may cause adverse side effects, therefore, the effects of $O$. gratissimum oil as anesthetics deserve investigation and cannot be overemphasized.

This study will shed more light and act a guide on stress management in fish farming and serves as an eye-opener in the uses of plant extract as anesthetics in Nigeria. The objectives of this study are to determine the use and dosage of $O$. gratissimum oil as anesthetic in $O$. niloticus juveniles. $\mathrm{H}_{0}=$ there are no anesthetic effects concerning blood biochemical parameters and hematology of $O$. niloticus. 


\section{Materials and Methods}

\section{Study area}

This study was conducted in the Department of Aquaculture and Fisheries Management, University of Ibadan, Nigeria. Ibadan is located on Latitude $10^{\circ} 23^{\prime} 0^{\prime \prime} \mathrm{N}$ and Longitude $12^{\circ} 5^{\prime} 0^{\prime \prime} \mathrm{E}$ (OYSG, 2015). Ibadan two major seasons which comprises of dry and rainy seasons. The dry season runs through November to March while rainy season starts around March to October with annual rainfall ranges 1500 to $1600 \mathrm{~mm}$ in 2015 [10].

\section{Plant collection and identification}

Fresh leaves of 0 . gratissiumum were obtained from a backyard in Agbowo, Ibadan and identified at the herbarium of the Forestry Research Institute of Nigeria (FRIN), Ibadan.

\section{Extract and dosage preparation}

Five (5) grams of $O$. gratissiumum was extracted in a Soxhlet apparatus using $170 \mathrm{ml}$ of di-ethyl ether [11,12]. The filtrate was concentrated on a rotary evaporator at $40^{\circ} \mathrm{C}$ for chemicals elimination, stripped into sterile bottles. The experimental treatment (dose) were prepared using 1:20 of extract and ethanol to have six concentrations $(0,20,40,60,80$, and 100 $\mathrm{mg} / \mathrm{l})$ [13]. Stages and effective concentrations for anaesthesia as described by Iwama et al., and Ross and Ross [14,15] were adopted in this study. The fish were placed in an induction tanks containing different dosages, observed for twenty minutes, transferred in to recovery tanks and observations were recorded.

\section{Experimental fish}

Fish (O. niloticus) with body weight ranges from 18.45 to 21.7 $\pm 3.2 \mathrm{gm}$ were purchased from Masopha Farm, Ibadan. The fish were transported to the Departmental Research Laboratory immediately in plastic container half-filled with water from the rearing tanks and conditioned for five (5) days in rectangular plastic tanks $(50 \times 34 \times 27 \mathrm{~cm})$ and fed twice a day ( $5 \%$ of body weight) with $40 \%$ crude protein commercial floating pelleted (Durantee) feed at 08:00 AM and 06:00 PM.

\section{Experimental design}

One hundred and eighty (180) O. niloticus juveniles were allocated into 18 transparent rectangular plastics (50 × $34 \times 27$ $\mathrm{cm}$ ) containing 35 litres of water in a completely randomized designed. The experiment has six treatments in triplicates. Each tanks were allotted ten fish thus 180 fish [Total number of fish $=$ (Number of treatment $\times$ number of replicates $\times$ number of fish per tank) $=6 \times 3 \times 10=180]$ fish. Water in each tank was replaced every three (3) day sourced from an industrial borehole.

\section{Monitoring of water qualities parameters}

LABTECH $^{\circledR}$ D.O. (Model AVI-660) and pH (Model Photoic 20) meters were used to monitor the D.O. and $\mathrm{pH}$ of the water in experimental tanks two times daily (08:00 AM and 6:00 PM) (just before feeding). Temperature was measured with the aid of mercury thermometer. The D.O., $\mathrm{pH}$ and temperature recorded ranges between $4.55 \pm 0.33$ to $5.86 \pm 1.03 \mathrm{mg} / \mathrm{l}, 6.52 \pm 0.46$ to $7.51 \pm 1.30$ and $23.79 \pm 1.43$ to $25.13 \pm 1.09^{\circ} \mathrm{C}$ respectively throughout the experimental period.

\section{Statistical analysis}

The data obtained from the experiment were subjected to one-way analysis of variance (ANOVA). Means were separated using Duncan's multiple range test (DMRT) at $p=0.05$ and regression was used to determine the relationship between induction/recovery time and extract concentration with means of SPSS statistical package version 20.

\section{Results}

Table 1 shows that the number of fishes anaesthetized was increased with increase in $O$. gratissimum oil concentration. Concentration of $100 \mathrm{mg} / \mathrm{l}$ anaesthetized highest number of fish $(10.00 \pm 0.00)$ while the least was observed in $20 \mathrm{mg} / \mathrm{l}(1.67 \pm$ 1.53). Recovery effect was examined and fish anaesthetized with the $20 \mathrm{mg} / \mathrm{l}$ of oil had highest number of recovered fish (10.00 \pm $0.00)$ while $100 \mathrm{mg} / \mathrm{l}$ had the least mean recovered fish (1.00 \pm 1.00).

Table 1 Induction and recovery at stage 3 of $O$. niloticus juveniles exposed to $O$. gratissimum oil

\begin{tabular}{|c|c|c|c|c|c|c|c|c|}
\hline \multirow{2}{*}{ Activities } & \multicolumn{8}{|c|}{ O. gratissimum oil inclusion level (mg/l) } \\
\hline & 0 (control) & 20 & 40 & 60 & 80 & 100 & F-cal & F-tab \\
\hline $\mathrm{NFI}$ & $0.00 \pm 0.00^{\mathrm{a}}$ & $1.67 \pm 1.53^{a}$ & $5.00 \pm 2.00^{b}$ & $8.67 \pm 1.53^{c}$ & $9.33 \pm 0.58^{c}$ & $10.00 \pm 0.00^{c}$ & 35.88 & 2.81 \\
\hline NFR & $0.00 \pm 0.00^{c}$ & $10.00 \pm 0.00^{c}$ & $8.67 \pm 1.15^{c}$ & $9.67 \pm 0.58^{c}$ & $5.33 \pm 1.53^{b}$ & $1.00 \pm 1.00^{a}$ & 47.15 & 2.81 \\
\hline IT (mins) & $0.00 \pm 0.00^{\mathrm{a}}$ & $8.52 \pm 1.13^{f}$ & $5.50 \pm 0.49^{e}$ & $3.51 \pm 0.34^{d}$ & $2.10 \pm 0.11^{c}$ & $1.02 \pm 0.03^{b}$ & 104.34 & 2.81 \\
\hline $\mathrm{RT}$ (mins) & $0.00 \pm 0.00^{a}$ & $1.00 \pm 0.43^{b}$ & $2.21 \pm 0.03^{b}$ & $3.35 \pm 0.27^{c}$ & $6.00 \pm 0.53^{d}$ & $9.24 \pm 1.06^{e}$ & 72.91 & 2.81 \\
\hline
\end{tabular}

Fish treated with higher concentrations anaesthetized faster than fish treated with lower concentration. The stage 3 of anaesthetization were reach within 3 to 4 minutes in fish treated with $60 \mathrm{mg} / \mathrm{l}$ while in higher and lower concentrations, 
anaesthetization were faster and lower respectively. There were statistical significant difference in number of fish induced, number of fish recovered, induction time and recovery time of the fish treated with $O$. gratissimum oil compared with the control as shown in Table 1.

Figure 1 shows the induction relationship and the concentration of oil $\left(y=8.85 x-94.66, R^{2}=0.892\right)$. Where $y=$ concentration of oil and $x=$ induction time. For any unit increased concentration of oil, there will be $(-8.85)$ decrease in time of induction.

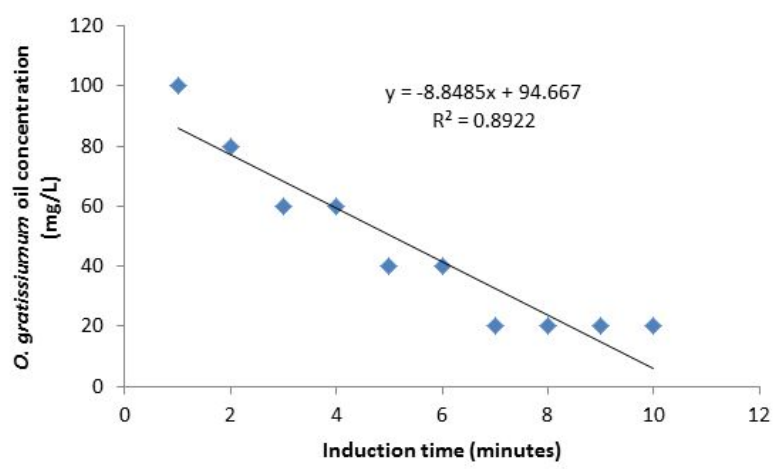

Figure 1 Relationship between induction time and concentration $O$. gratissimum oil.

Figure 2 shows the recovery time relationship and the concentration of oil $\left(y=8.48 x+25.33, R^{2}=0.905\right)$. Where $y=$ concentration of oil and $x=$ recovery time. For any unit increased concentration of oil, there will be (8.48) increase in recovery time of induction.

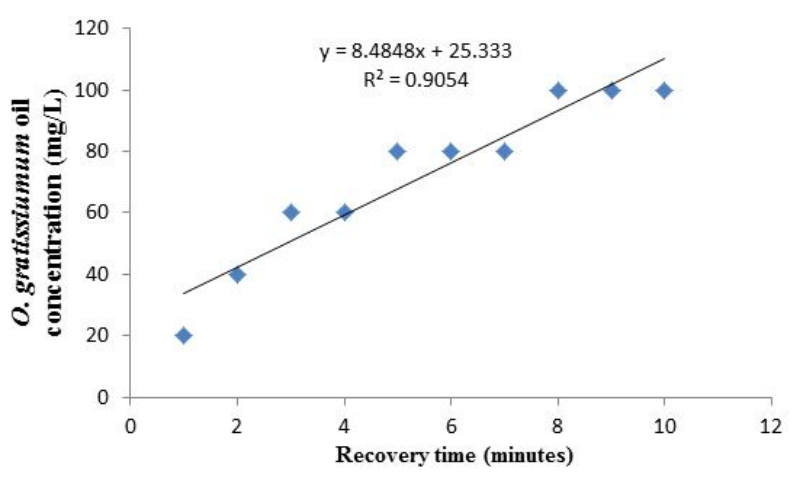

Figure 2 Relationship between recovery time and concentration $O$. gratissimum oil.

\section{Discussion}

The result of this study shows that lower dosages did not achieve stage 3 inductions (i.e. cessation of operculum) although there was some sign of loss of mobility in few fish. The $O$. gratissimum oil concentration of $60 \mathrm{mg} / \mathrm{l}$ and above anesthetized most of the fish and up to $100 \%$ in $100 \mathrm{mg} / \mathrm{l}$. the
$60 \mathrm{mg} / \mathrm{l}$ was considered adequate for anesthetic activities on O.niloticus. The result further shows that there is statistical significant difference in the effect of oil concentration in induction performance of $O$. gratissimum on $O$. niloticus but separating the means using Duncan Multiple Range Test shows that is no statistical significant difference among the 60,80 and $100 \mathrm{mg} / \mathrm{l}$ concentration of the oil. F-calculated is greater than Ftabulated hence the null hypothesis is rejected. The result observed in this study agreed with the work of Ribeiro et al. who reported that concentration of 0 . gratissiumum oil above 40 $\mathrm{mg} / \mathrm{l}$ is adequate for anesthetized $O$. niloticus. Recovery time shows that the decrease in concentration of the oil the faster the fish recovered from the induction. Majority of the fish anesthetized with concentrations between 40 and $60 \mathrm{mg} / \mathrm{l}$ recovered within three minutes and therefore considered adequate. The result further revealed that concentration of the oil is statistically significant different on the recovery of the fish showing F-calculated greater than F-tabulated hence the null hypothesis is rejected. The result is in agreement with the work of Roubach et al., Barbosa et al., Maraka et al., Ribeiro et al. [16-19].

However, the 0 . gratissimum oil can be used as anesthetic material in O. niloticus at $60 \mathrm{mg} / \mathrm{I}$ concentration. Therefore, uses of naturally produce anesthetics will reduce residual effect of continuous use of chemicals in aquaculture [20]. In today fish farming and research, handling fish, from measuring for production purposes to sales, injuries of the fish, stress and that of handlers cannot be completely removed hence it could be reduced if the fish is anesthetized using 0 . gratissimum oil without any significant negative effect.

\section{References}

1. Adakole JA (2012) Changes in some Haematological parameters of the African catfish (Clarias gariepinus) exposed to a metal finishing company effluent. Indian J Sci Technol 5: 2510- 2514.

2. Adeshina I (2016) Use of phytogenic extract in control \& management of listeriosis in farm raised African catfish in Oyo State. Ph.D. Progress-Report, University of Ibadan.

3. Barata $M$, Sores F, Aragao C, Almeida AC, Pousao-Ferreira P, et al. (2016) Efficiency of 2-phenoxyethanol \& clove oil for reducing healing stress in reared meager, Argyrosomus regius (Pisces: Sciaenidae), J World Aquacult Soc 47: 82-92.

4. Barbosa LM, Moraes G, Inoue LAKA (2007) Respostas metabólicas do matrinxã submetido a banhos anestésicos de eugenol. Acta Sci Bio Sci 29: 255-260.

5. Bayoub K, Baibai T, Mountassif T, Retmane A, Soukri A (2010) Antibacterial activities of the crude ethanol extracts of medicinal plants against Listeria monocytogenes \& some other pathogenic strains. Afr J Biotechnol 9: 4251-4258.

6. Correa MP (1932) Dicionario das plantas uteis do Brasil. IBDF, Rio de Janeiro.

7. El-Hawarry WH (2012) Biochemical \& non-specific immune parameters of healthy Nile tilapia (Oreochromis niloticus), Blue tilapia (Oreochromis aureus) \& their interspecific hybrid (male $\mathrm{O}$. aureus $\times$ female $O$. niloticus) maintained in semiintensive culture system, OJAFR 2: 84-88. 
8. Gafaar AY, El-manakhly EM, Soliman MK., Soufy H, Monas Z, et al. (2010) Some pathological, biochemical \& Haematological investigation on Nile tilapia (Oreochromis niloticus) following chronic exposure to edifenphos pesticide. J Am Sci 6: 542-551.

9. Hema R, Kumaravel S, Sivasubramanian C (2010) GC-MS study on the potentials of Syzygium aromaticum. Researcher 2: 1-4.

10. Ilori M, Sheteolu AO, Omonibgehin EA, Adeneye AA (1996) Antibacterial activity of Ocimum gratissimum (Lamiaceae). J Diarrhoeal Dis Res 14:283-285.

11. Iwalokun RA, Gbenle GO, Adewole TA, Smith SI, Akinsinde KA, et al. (2003) Effects of Ocimum gratissimum L. essential oil at subinhibitory concentration on virulent \& multi drug resistant Shigella strains from Lagos, Nigeria. APMIS 3: 477-482.

12. Iwama GK, McGeer JC, Pawluck MP (1989) The effect of five fish anesthetics on acid-base balance, hematocrit, blood gases, cortisol, \& adrenaline in rainbow trout. Can J Zool 67: 2065-2073.

13. Lemos Jde A, Passos XS, Fernandes Ode F, Paula JR, Ferri PH, et al. (2005) Antifungal activity from Ocimum gratissimum L. towards Cryptococcus neoformans. Mem Inst Oswaldo Cruz 100: 55-58.

14. Kefas M, Abubakar KA, Ja'afaru A (2015) Haematological indices of tilapia (Oreochromis niloticus) from Lake Geriyo, Yola, Adamawa State, Nigeria. Int J Fish Aquat Stud 3: 9-14.
15. Kreiberg H (2000) Stress and anesthesia. In: Ostrander GK, editor. The Laboratory Fish. New York: Academic Press: 503-511.

16. Matasyoh LG, Matasyoh JC, Wachira F, Kinyua M, Muigai A, et al. (2007) Chemical composition \& antimicrobial activity of the essential oil of Ocimum gratissimum L. growing in Eastern Kenya. Afr J Biotechnol 6: 760-765.

17. Onajobi FD (1986) Smooth muscle contracting lipid soluble principles in chromatographic fractions of Ocimum gratissimum. J Ethnopharmacol 18: 3-11.

18. Ribeiro AS, Batista ES, Dairiki JK, Chaves FCM, Inoue LAKA (2016) Anesthetic properties of Ocimum gratissimum essential oil for juvenile matrinxã. Acta Sci Anim Sci 38: 1-7.

19. Ross LG, Ross B (2008) Anesthetic \& sedative techniques for aquatic animals. 3rd edn. Blackwell Publishing: Oxford, UK.

20. Roubach R, Gomes LC, Fonseca FAL, Val AL (2005) Eugenol as an efficacious anesthetic for tambaqui (Colossoma macropomum). Aquacult Res 36: 1056-1061. 